\title{
SYSTEMATIC APPROACH TO THE ANALYSIS OF OCCUPATIONAL INJURIES IN POTASH SALT PRODUCING ENTERPRISES
}

\author{
Shwager N. \\ Kryvyi Rih National University, doctor of technical sciences, Profes- \\ sor, Ukraine \\ Komisarenko T. \\ Kryvyi Rih National University, PhD, Associate Professor, Ukraine \\ Nesterenko O., \\ Kryvyi Rih National University, PhD, Associate Professor, Ukraine \\ Bliznukova $\mathbf{O}$. \\ Kryvyi Rih National University, PhD, Associate Professor, Ukraine
}

\begin{abstract}
The aim of this work is to analyze the industrial injuries at potassium salt mining enterprises on the basis of a systematic approach and to develop of recommendations to prevent accidents, reduce the probability of industrial injuries and occupational diseases.

Methods. The system approach was taken as a basis for the research. The data on the main causes of accidents are analyzed, and indicate the urgent need to take into account the peculiarities of injury and death of workers, the development and implementation of measures to improve the safety of the industrial environment. The functioning of the occupational safety management system has been assessed. It is carried out on the basis of health and safety criteria - analysis and evaluation of the results of inspections, according to which measures aimed at improving health and safety are developed.

Results. The presented method of analysis of risks and industrial injuries makes it possible to offer a set of solutions in the field of safe development of potash deposits, taking into account that employees of all levels should be actively involved in health and safety management. The standards particularly emphasize the importance of occupational safety training, professional development and competence of personnel (their knowledge and skills). The enterprise should control the level of knowledge of the employee regarding his or her health and safety responsibilities, the results of his or her actions in terms of safety, understanding of his or her responsibility, including actions in emergency situations, and possible consequences of noncompliance with technological instructions.
\end{abstract}




\section{Statement of the problem and its connection with scientific and practical tasks.}

The level of industrial injuries is the main indicator of the state of labor protection in any area of economic activity and in the state as a whole. According to experts, losses in the economy from one fatal or severe accident are tentatively estimated at $\$ 75,000$. Accidents without a severe outcome (with loss of ability to work), absenteeism due to illness, employee turnover result in the loss of about 100 thousand person-days per year [1]. Insurance payments for compulsory insurance against industrial accidents and occupational diseases amount to about \$ 25 million annually, and about \$ 130 million to compensate for adverse working conditions [2; 3].

According to statistics from the International Labor Organization, one person dies every three minutes as a result of an accident or occupational disease in the world, and every second four workers are injured. This number of injured exceeds the number of injured in traffic accidents, [1]. The total number of people injured by accident in the workplace is 270 million people a year, about 160 million more people suffer from diseases associated with labor activity. When extracting potassium salts according to official data, more than 5 thousand workers are injured annually due to violations of labor protection requirements at the workplace, of which about 250 people die, more than 800 people are seriously injured [2].

Data on the main causes of industrial accidents indicate the urgent need to take into account the characteristics of injuries and deaths of workers when developing and implementing measures to improve the safety of the working environment [4].

Problem statement. The aim of this work is to analyze occupational injuries in enterprises producing potash salts based on a systematic approach. Development on this basis of recommendations for preventing the occurrence of accidents, reducing the likelihood of work-related injuries and occupational diseases.

Analysis of research and publications. Of practical interest is a risk management in accordance with labor protection policies and goals. It is carried out in the context of a general growth of interest in labor protection issues [5].

Many enterprises conduct analyzes or audits in the field of labor protection in order to evaluate the effectiveness of the OSH manage- 
ment system. However, these measures alone are not sufficient to ensure that OSH management system meets the requirements stipulated by legislation and labor protection policy. Analyzes and audits at the enterprise should be carried out within the framework of a structured management system integrated into the management of the organization. OSH standards are designed to provide enterprises with elements of an effective labor protection management system that can be implemented along with other management elements to achieve goals in the field of labor protection [5].

The main one is the OHSAS 18001 standards system, which provides for the implementation of management and administration of occupational health and safety at work. The main attention of the standards of the OHSAS 18001 series is aimed at ensuring the safety of workers [6]. These standards are used by enterprises to minimize the risks and dangers associated with their production activities.

Statement of the main research material.Belarus is one of the largest producers and exporters of potash fertilizers in the world. According to the International Fertilizer Association, it accounts for one fifth of the global potash fertilizer production. Having a sufficient natural raw material base, high production potential of workers and specialists, enterprises cope with these tasks by introducing new equipment and improving technological processes.

The labor protection and industrial safety management system (OSHMS PB) is a fundamental document on labor protection and industrial safety management and is developed in accordance with the requirements of STB 18001, OHSAS 18001 [6,7].

SUOT PB establishes the main tasks of conducting preventive work on labor protection and the implementation of production control at the production facilities of enterprises and is mandatory for all employees.

The main tasks of the OSH management system are:

- the fulfillment by workers of the requirements for labor protection and industrial safety in the decision-making process during the organization and execution of work;

- the constant formation of safe employee behavior in the workplace, the implementation of labor discipline, taking into account the psychology of the individual;

- minimization or elimination of risks for employees; 
- Continuous improvement in the field of labor protection and industrial safety;

- increasing the responsibility of each employee for the fulfillment of their duties to create safe working conditions and timely elimination of the reasons that could lead to work injury, accident, incident;

- implementation of production control by managers and specialists.

An assessment of the functioning of the OSH management system is carried out on the basis of labor protection criteria - analysis and evaluation of the results of inspections, according to which measures aimed at improving the state of labor protection are developed.

The control procedures and evaluation of the effectiveness of the OSH management system and its elements are the basis for the development of appropriate measures to improve working conditions.

Control procedures are carried out with the involvement of personnel who have been trained and instructed in the field of labor protection in the following areas:

- monitoring the implementation of planned labor protection measures;

- continuous monitoring of the state of the production environment;

- multistage control of the state of working conditions at the workplace;

- check the readiness of the organization to work in the autumnwinter period;

- internal audit (audit) of the management system;

- external verification (audit) by the certification body.

Evaluation of the effectiveness of the system is carried out according to the following criteria: statistical reporting on the state of working conditions of workers - information on the state of working conditions and compensation for work in harmful and (or) dangerous working conditions and on the status of injuries; the results of the investigation of accidents, occupational diseases and industrial incidents and their impact on safety and health; analysis of occupational injuries; assessment of the effectiveness of the OSH management system and its elements.

For this, taking into account the complexity, danger and technical equipment of units, depending on the number of employees, the pos- 
sibility of using a set of indicators and their achievement, basic integrated indicators are established annually in the enterprise units. The basic integrated indicator and the calculated integrated indicator for units and management as a whole is determined as the arithmetic average of the integrated indicators for units.

The use of a safety assessment indicator in practice makes it possible to identify and describe all sources of hazards, evaluate risks, provide management measures, substantiate and develop measures to reduce risks to acceptable levels.

When identifying possible dangers (dangerous situations) associated with the fulfillment of labor duties by employees, the OSH determines that the sources of dangers may be:

- equipment used in the work or affecting the employee;

- environment and production environment;

- the person (working or student enterprise, the visitor, the representatives of other organizations).

In the process of identifying potential hazards (dangerous situations), characteristic for the activities of units and employees (enrolled in the enterprise), head of structural unit may determine the hazards (dangerous situation), not previously entered in the register of hazards. In this case, the head of Department updates the register of hazards and risks and bring the updated document to stakeholders.

To date, developed a variety of documents on implementation of hazard analysis and risk assessment in industrial plants $[8,9,10]$.

Are the fundamental documents OHSAS 18001:2007 "management System occupational safety and health"; OHSAS 18002:2008 "management System safety and health. Guidance for use". In these documents the necessity, principles and methods of hazard identification and estimation of occupational risks for workers. Also known standard ISO/IEC 31010:2009 "risk Management. Risk assessment techniques" (ISO/IEC 31010:2009 "Risk management - Risk assessment techniques"). It contains recommendations for selection, depending on initial conditions, methods to assess production risks. The standard lists the 31 method of analysis (for example: brainstorming; Delphi technique; evaluation of Toxicological risk; analysis of the fault tree analysis; causal analysis; the study of hazard and operability (HAZOR); Markov analysis; simulation Monte-Carlo, etc.). 
The International Social Security Association (ISSA) has developed the Zero Injury Concept, or Vision Zero. In September 2017, the 21 st World Congress on Occupational Safety and Health in Singapore launched a global international campaign to promote and implement this concept.

Zero Injury, or Vision Zero.

This is a qualitatively new approach to the organization of prevention, combining three areas - safety, occupational health and wellbeing of workers at all levels of production.

The Vision Zero concept developed by ISSA is flexible and can be adapted to any place of work, at any enterprise in any industry in all regions of the world [11].

When conducting hazard identification and risk assessment, the following are considered:

- normal working conditions (planned activities of employees in accordance with the requirements of regulatory documents);

- non-standard (emergency) working conditions (in case of deviations from normal activities, accidents, disasters, incidents, etc.).

There is a large number of documents on identification, analysis and risk assessment at industrial enterprises

The ballast method is used to assess the risks at potash production facilities.

The risk assessment is carried out by the formula below

$$
R=S \times P r,
$$

where $R$ is the estimated risk, in points; $S$ - severity of damage from exposure to a specific hazard, in points; $\operatorname{Pr}$ - probability of a specific hazard, in points

$$
\operatorname{Pr}=S t \times P \times D \times C,
$$

where $S t$ - hazard statistics; $P$ - coefficient of exposure of workers to the effects of danger, in points; $D$ - coefficient characterizing the frequency (duration) of exposure to a specific hazard, in points; $C$ coefficient determined by the probability of failure to take measures to control the impact of a specific hazard (taking into account the human factor), in points.

The quantification of the severity of the harm caused by the specific hazard is determined in Table 1. 
Table 1

Severity of harm assessment

\begin{tabular}{l|l|l}
\hline $\begin{array}{l}\text { The severity of } \\
\text { harm from expo- } \\
\text { sure to a specific } \\
\text { hazard, St }\end{array}$ & $\begin{array}{l}\text { Consequences of } \\
\text { exposure to haz- } \\
\text { ards }\end{array}$ & The severity of the consequences \\
\hline 1 & minimal & $\begin{array}{l}\text { Slight impact, painful sensations, } \\
\text { fatigue }\end{array}$ \\
\hline 1.5 & moderate & Disability accident, micro-injuries \\
\hline 3.0 & significant & $\begin{array}{l}\text { Disability accident, no threat to life } \\
\text { (non severe injury) }\end{array}$ \\
\hline 4.0 & considerable & $\begin{array}{l}\text { Injury related to serious, occupational } \\
\text { disease }\end{array}$ \\
\hline 5.0 & catastrophic & $\begin{array}{l}\text { Fatal accident, group accident with } \\
\text { severe consequences, fatal accident }\end{array}$ \\
\hline
\end{tabular}

The statistics of hazard occurrence is given in Table 2 .

Table 2

Hazard statistics

\begin{tabular}{l|l}
\hline Hazard statistics, St & Frequency of danger \\
\hline 1 & No injuries \\
\hline 1.5 & 1 case of injury during 10 years of work \\
\hline 2.0 & 2 cases of injury during 10 years of work \\
\hline 3.0 & 3-4 injuries during 10 years of work \\
\hline 4.0 & 5 or more injuries during 10 years of work \\
\hline
\end{tabular}

Depending on the level of safety of technological processes, the state of equipment, the degree of safety of workers, the coefficient of exposure of workers to danger is determined, the values of which are given in Table 3.

Table 3

Ratio of exposure of workers to the hazard

\begin{tabular}{l|l|l}
\hline $\begin{array}{l}\text { Operating } \\
\text { Hazard } \\
\begin{array}{l}\text { Exposure } \\
\text { Coefficient, } \\
\mathrm{P}\end{array}\end{array}$ & $\begin{array}{l}\text { Exposure to } \\
\text { danger }\end{array}$ & $\begin{array}{l}\text { Safety characteristics of the used equipment, } \\
\text { processes and the degree of employee protec- } \\
\text { tion }\end{array}$ \\
\hline 1 & minimum & \\
\hline 2 & moderate & \\
\hline
\end{tabular}


Continuation of table 3

\begin{tabular}{l|l|l}
\hline 3 & significant & $\begin{array}{l}\text { Used equipment is practically not worn out, } \\
\text { undergoes periodic maintenance (inspection), is } \\
\text { equipped with protective devices to prevent the } \\
\text { impact of this danger at the workplace. } \\
\text { Qualified personnel provided with individual } \\
\text { and collective protection means are allowed to } \\
\text { work. }\end{array}$ \\
\hline 4 & High & $\begin{array}{l}\text { Used equipment is practically not worn out, } \\
\text { undergoes periodic maintenance (inspection), is } \\
\text { equipped with protective devices. The techno- } \\
\text { logical documentation for individual operations } \\
\text { is not developed. Qualified personnel, partially } \\
\text { provided with individual and collective protec- } \\
\text { tion means, are allowed to work. }\end{array}$ \\
\hline 5 & $\begin{array}{l}\text { Used equipment of own manufacture or practi- } \\
\text { cally worn out, the fact of passing maintenance } \\
\text { (examination, testing) is not established, } \\
\text { equipped with separate protective fences. Work } \\
\text { performance is not regulated by safety } \\
\text { measures set out in the technological documen- } \\
\text { tation. }\end{array}$ \\
\hline
\end{tabular}

The coefficient D characterizing the frequency (duration) of exposure to a particular hazard is determined by Table 4 .

Table 4

Coefficient characterizing the frequency (duration) of exposure to a specific hazard

\begin{tabular}{l|l}
\hline Value D, score & Description of the duration of exposure to a specific hazard \\
\hline 0.5 & Isolated (once a year, once every few years) \\
\hline 1 & Minimum (several times a year) \\
\hline 1.2 & Random (once a month) \\
\hline 1.5 & Temporary (once a week) \\
\hline 2.5 & Frequent (every day) \\
\hline 3.0 & Continuous exposure \\
\hline
\end{tabular}

The manifestation of the human factor (coefficient D), is determined by Table 5 .

When determining the coefficient, cases of injuries of employees of a given profession, which occurred at a particular workplace, are taken into account. 
Coefficient of human factor manifestation

\begin{tabular}{c|l}
\hline $\begin{array}{c}\text { Value C, } \\
\text { score }\end{array}$ & $\begin{array}{l}\text { Description of the probability of failure to implement measures to } \\
\text { manage the impact of the hazard }\end{array}$ \\
\hline 1 & $\begin{array}{l}\text { The probability of failure to implement hazard management measures is } \\
\text { low (less than } 10 \%)\end{array}$ \\
\hline 1.1 & $\begin{array}{l}\text { The probability of failure to implement the hazard management measures } \\
\text { is low. (10\% to } 25 \%)\end{array}$ \\
\hline 1.2 & $\begin{array}{l}\text { The probability of failure to implement hazard management measures is at } \\
\text { an average level. Such violations are not systematic (25\% to 50\%) }\end{array}$ \\
\hline 1.3 & $\begin{array}{l}\text { The probability of failure to comply with the hazard management } \\
\text { measures is high. Violations occur quite regularly and/or within a certain } \\
\text { time interval (50\% to 75\%). }\end{array}$ \\
\hline 1.4 & $\begin{array}{l}\text { The probability of failure to implement the hazard management measures } \\
\text { is very high. Disturbances always occur for a sufficiently long period of } \\
\text { time (usually under normal operating conditions) (75\% or more). }\end{array}$ \\
\hline
\end{tabular}

Conclusions. The presented method of risk analysis and industrial injuries allows us to propose a set of solutions in the field of safe development of potash salts, taking into account the fact that workers of all levels should be actively involved in the management of labor protection.

The standards especially emphasize the importance of training on labor protection issues, staff development and competence (their knowledge and skills).

The enterprise must control the level of knowledge of the employee regarding his labor protection duties, the results of his actions in terms of safety, understanding his responsibility, including actions in emergency situations, as well as the possible consequences of noncompliance with technological instructions.

Once every five years, certification of jobs should be carried out and a map of working conditions should be drawn up.

Measures to reduce risk may be associated with:

- introduction of additional requirements, revision, amendment, development of local regulatory acts on labor protection and industrial safety (including instructions on labor protection); 
- additional training, briefing on safe work methods, periodic and production control;

- repair, modernization, reconstruction or replacement of faulty and obsolete equipment;

- the use of a safer way to perform work (alarm, blocking, etc.);

- preventing access to hazardous and harmful production factors;

- the organization of work in a way that reduces the impact of a harmful or dangerous production factor;

- the issuance of additional personal protective equipment, their replacement, etc.

Consequently, hazard identification, risk assessment and control should be the basis of the entire OSH management system.

\section{References}

1. Solovyov, V.A.; Sekuntsov, A.I.( 2013) Development of the potash deposits: workshop. - Perm: Izdvo Perm National Research Polytechnic University,.

2. E.N. Baturin, E.A. Menshikova, S.M. Blinov, D.Y. Naumov, P.A. Belkin

(2012)// Problems of the world largest potassium deposits development [Electron resource] Modern problems of science and education.

3. Mihniuk, T.F. (2015) Life safety : ed. - Minsk : data center of the Ministry of Finance.

4. Schwager N.Y., Zaikina D.P. (2015) Sertifikatsiyi system of management of security guards, which is the basis of the late politics in the gallery of security guards at the enterprise. - Girnichyy Visnik :Nauk. - a technical visitor. - Krivij Rig. Vip. $99,111-115$.

5. ST. 18001-2009. - Labor protection management systems. Requirements. (OHSAS 18001:2007, NEQ.- Minsk. 2009 г. № 19

6. OHSAS 18001:2007 - "Occupational Health and Safety Management System.Requirements".

7. Vysotskiy, E. Vysotskiy A., Gubin V, Kutyrlo V.(2007) Economic and geographical aspects of the world potassium industry. Vestnik BGU. Chemistry series. Biology // Vestnik BGU. Geography // Vestnik BSU. № 1, 90-96.

8. Manual for monitoring working conditions at a workplace in industry. The Elmeri System. (2nd updated edition) // Finnish Institute of Occupational Health. Helsinki, 2000 - 26 p.

9. Mervi Murtonen. Workplace Risk Assessment - A Practical Guide: The Occupational Safety and Health Series: International Experience. Issue 1. - M.: ILO Subregional Office for Europe and Central Asia, 2007. - 64c.

10. Occupational risk. Theory and practice of calculation / Under the editorship of A.G. Khrupachev, A.A. Khadartsev.- Tula: TulSU Publishing House, 2011.330 p. 6.

11. International Association of Social Security. - 2017.-20c. ISBN-978-92-843$5222-7$. 